\title{
The Temperature Evaluation of the Buried Hill Geothermal Reservoirs in the Jizhong Depression, Bohai Bay Basin, China
}

\author{
Yuyang Dong $\mathbb{D}^{1,2}$ Jianhui Zeng ${ }^{\mathbb{D}},{ }^{1,2}$ Xianzheng Zhao, ${ }^{3}$ Yanu Wang, ${ }^{1,2}$ Tianhao Chen, ${ }^{1,2}$ \\ Yongchao Zhang, ${ }^{4}$ and Sen Feng ${ }^{1,2}$ \\ ${ }^{1}$ State Key Laboratory of Petroleum Resources and Prospecting, China University of Petroleum, Beijing 102249, China \\ ${ }^{2}$ College of Geosciences, China University of Petroleum, Beijing 102249, China \\ ${ }^{3}$ Dagang Oilfield Company, PetroChina, Tianjin 300280, China \\ ${ }^{4}$ Qingdao Institute of Marine Geology, China Geological Survey, Qingdao 266071, China
}

Correspondence should be addressed to Jianhui Zeng; zengjh@cup.edu.cn

Received 15 August 2019; Revised 14 March 2020; Accepted 31 October 2020; Published 23 November 2020

Academic Editor: Glenda Taddia

Copyright (C) 2020 Yuyang Dong et al. This is an open access article distributed under the Creative Commons Attribution License, which permits unrestricted use, distribution, and reproduction in any medium, provided the original work is properly cited.

\begin{abstract}
The Jizhong Depression is located in the western Bohai Bay Basin, eastern China. The deep strata are mainly composed of carbonate buried hill, and the shallow strata are a mainly siliciclastic deposition. In the present work, the Na-K-Mg triangle diagram and geothermometers were used to investigate the geochemical characteristics of shallow groundwater and reservoir temperature features of three geothermal reservoirs in the depression, including the Ordovician, the Cambrian, and the Precambrian Wumishan Formation. The results showed that the geothermal water in the depression could be divided into three groups: group I, $\mathrm{Cl} \cdot \mathrm{HCO}_{3}-\mathrm{Na}$ type; group II, Cl-Na type; and group III, Cl-Na-Ca type. By using the $\mathrm{Na}-\mathrm{K}-\mathrm{Mg}$ triangle diagram, group II and group III geothermal water samples were identified as the partially equilibrated water, whose temperature of the geothermal reservoir can be calculated based on the cation geothermometers. The ranges of the calculated temperature of the shallow strata and the deep strata are $91 \sim 146^{\circ} \mathrm{C}$ and $147 \sim 176^{\circ} \mathrm{C}$, respectively. It has the good results obtained with some cation geothermometers in a geothermal system hosted in carbonate rocks like the studied area. The analysis workflow and calculation data obtained in this work contribute to the evaluation of the temperature field and the exploration and development of the geothermal resources in the Bohai Bay Basin.
\end{abstract}

\section{Introduction}

Many countries around the world are engaging in research on new energy, especially on renewable energy, in order to gradually reduce their nation's dependence on traditional fossil fuels. There are roughly 82 countries (regions) making use of geothermal energy directly and 26 countries (regions) using geothermal energy for power generation. China's geothermal resources account for about $16.7 \%$ of global resources, especially the medium- and low-temperature geothermal resources, which means that the geothermal energy sector has great development potential. It is shown that there has been a rapid development in geothermal utilization in the past few years and the installed capacity of geothermal power generation will increase by $1 \mathrm{GWe}$ per year in the next 6 and 7 years [1].

Geothermal and petroleum resources coexist in sedimentary basins. With most of the oilfields in eastern China entering the middle and late stages of development, the difficulty of oil and gas exploitation gradually increases, and the proportion (water content) and the total amount of water in the produced fluid are also increasing. The water content of the old oilfields in the east is more than $90 \%$ on average [2]. In a sense, the reservoirs in these oilfields are no longer oil but water. More and more wells have been abandoned in these oilfields when the petroleum reservoir was depleted without economic feasibility. The oilfield has a large amount 
of detailed geological data, which provides important basic data for the development and utilization of geothermal resources.

Drilling costs can account for 50\% of geothermal projects. If the abandoned oil and gas wells are transformed into geothermal wells after the thermal storage temperature assessment, drilling costs can be greatly reduced and the geothermal project can be launched [3]. In the late stage of oilfield development, abandoned oil and gas wells can be transformed into geothermal wells and utilized as geothermal wells $[4,5]$. Kujawa et al. $[6,7]$ introduced the double-pipe well hole heat exchanger, which is the simplest kind of geothermal borehole heat exchanger, used for heat extraction from abandoned oil and gas wells. In recent years, some scholars have continued their research on obtaining thermal energy from abandoned oil and gas wells [8-10]. Getting geothermal energy from abandoned oil and gas wells has the following four advantages. There is no drilling investment (costs can be saved) and no groundwater extraction (corrosion problems can be avoided), thermal properties of wells are available, and retrofitting wellbore with equipping the inner pipe is a proven technology [11]. In the Bohai Bay Basin, some abandoned oil wells have been retrofitted, such as wells Y1 and L24 in Huabei Oilfield [12] and wells T38-1 and T38-2 in Dagang Oilfield [13]. Huabei Oilfield uses recharge wells to inject water into geothermal reservoirs and then uses geothermal wells to extract hot water to develop geothermal energy. There is a certain distance (minimum $200 \mathrm{~m}$ ) between recharge wells and geothermal wells to achieve heat exchange [12].

Geothermometry is a method that uses the concentration or concentration ratio of the chemical components to calculate the temperature of an undergroud geothermal reservoir. The method is based on the hypotheses that water and hydrothermal (secondary) minerals quickly attain the equilibrium condition in the geothermal reservoir and that no water-rock interaction and no interfering process (e.g., mixing and boiling) take place while the geothermal fluid is rising to the earth's surface $[14,15]$. In the 1970s 1980s, experts and scholars established a series of geothermometers to estimate the temperature of geothermal reservoirs, including silica geothermometers, cation geothermometers, and isotope geothermometers, which are widely used in the development and utilization of geothermal resources [14-17]. From 1988 to 1992, a series of triangular figures were created for the study of the origin and formation mechanism of geothermal fluids $[18,19]$. From 1997 to 2002, some scholars proposed some improvements to the geothermometers. Verma and Santoyo [20] proposed three improved equations for the widely used $\mathrm{Na}-\mathrm{K}, \mathrm{Na}-\mathrm{Li}$, and silica geothermometers and compared them with the equations by Fournier and others, which find that the total propagated errors of the new equation are smaller than the original equation. Bayram [21] and Can [22] developed a new Na-K geothermometer based on artificial neural networks (ANNs), respectively. Bayram also compared seven $\mathrm{Na}-\mathrm{K}$ geothermometers for predicting geothermal fields and considered that the reservoir temperatures of some geothermal fields in Turkey determined by the new method are consistent with those determined by other methods [21]. Using the Na-K-Mg triangle diagram, Zheng et al. [23] consider that the cation geothermometer can estimate the water samples in the Guanzhong Basin; the calculation results were similar; and after studying the silica equilibrium with selected geothermal water samples, the results show that chalcedony has a better fit than quartz, which inferred that chalcedony controls the silica concentration in the deep reservoir. By using the $\mathrm{Na}-\mathrm{K}-\mathrm{Mg}$ triangle diagram, cation geothermometers were not applicable in southern Tunisia; Kamel used the Na-Li geothermometer to estimate the temperature of the thermal water, finding that the results obtained are credible, compared with results of previous studies [24]. Nitschke et al. [25] considered that the $\mathrm{Na}^{+}$ $/ \mathrm{K}^{+}$concentration ratio in fluids is obviously not unequivocally controlled by temperature but is also dependent upon reservoir rock composition. Blasco et al. studied the Tiermas geothermal system in the Jaca-Pamplona Basin, with two groups of different total dissolved solids and waters in the carbonate rock, and results show that there are slight differences in the temperature of depth and in the concentration of some chemical compositions. They also found the good results obtained with cationic geothermometers in a geothermal system of low temperature and hosted in carbonateevaporitic rocks like the studied area, which may be attributed to the presence of detrital rocks (silicate minerals) in the carbonate-evaporitic reservoir [26].

The Jizhong Depression is a sedimentary basin developed in the Mesozoic and Cenozoic era. The depression is rich in oil and gas resources, the study of which has been quite sufficient [27-31]. Based on the research of Zhang et al., the depression belongs to the type of sedimentary basin nonmagma origin. There are two main heat sources in the depression, one is the conduction heat from the deep earth, and the other is generated by the radioactive materials in the strata, mainly in the forms of conductive heat transfer, with regional hydrothermal convection. The depression has no additional heat source (the heat generated by magma) [32]. The plane distribution characteristics of the heat flow in the study area are related to the relief of the basement, and the basement uplift is a relatively high-temperature zone [33]. At the same time, the hydrodynamic condition is one of the important influencing factors causing the differences in geothermal fields in different regions of the depression. The geothermal reservoirs in the depression are adjacent to the heat resources, and most of them have good cap rock, which mainly includes pore type, fracture type, and fracture-cavern type [34]. He and Ma proposed a conceptual model for the formation mechanism of Ordovician carbonate thermal reservoirs in the North China Plate by analyzing the hydrochemical characteristics, hydrochemical types, and characteristic coefficients [35]. Zhao et al. studied the hydrochemical characteristics of the Baxian sag in the depression, considering that the characteristics could be divided into three types according to their different chemical composition, the origin and formation mechanism of which were also studied [28]. However, the estimation of the geothermal resources in the depression, especially the temperature of the geothermal reservoir, has not received sufficient attention.

This paper analyzes the geochemical characteristics of the geothermal water in the buried hill of the study area and divides these samples into groups. Then, determine whether each group is suitable to calculate the temperature of the 
geothermal reservoir with a cation geothermometer and estimate the temperature. After obtaining the calculation results, compare the results with the bottom hole temperature (BHT) to verify the reliability of the results. Through the research of this paper, a scientific basis for the development and utilization of the geothermal resources in the study area will be provided.

\section{Basic Geology Settings}

2.1. Geological Settings. Located in the western part of the Bohai Bay Basin, the Jizhong Depression is a Mesozoic and Cenozoic sedimentary depression developed in the basement of the ancient platform in North China $[4,33]$. With an area of about $3.2 \times 10^{4} \mathrm{~km}^{2}$, the Jizhong Depression shows a northeast-southwest trend and is bounded by the Yanshan uplift in the north, the Xingheng uplift in the south, the Taihangshan uplift in the west, and the Cangxian uplift in the east. According to the characteristics of the basement relief and fault distribution, the central depression can be divided into several secondary structural units [33]. In general, the depression shows the characteristics of "one convex and two concaves"; that is, the central uplift zone divides the Jizhong Depression into the western and east depression zones. The central swell belt mainly includes Daxing, Niuzhai town, Rongcheng, Gaoyang, Wuji, and Ningjin. The western depression zone mainly includes sags such as Beijing, Xushui, Baoding, and Shijiazhuang. The eastern depression zone mainly includes Langgu, Wuqing, Baxian, Raoyang, Shenxian, Shulu, Jinxian, and other sags (Figure 1).

There are three types of faults in the study area: NNE, NE, and SW trending $[4,36]$. The NNE-trending faults are the most developed group of faults in this area. They are large in scale, long in extension and steep in dip. In Cenozoic, fault activity was still intense and controlled the Oligocene deposition process. The north-easterly faults are in the same direction as the axial direction of the basement folds, most of which distribute in the axis part of the basement folds and low angle. In comparison, the SW-trending faults are much smaller. As a result, these faults control the area of geothermal fields in the depression.

According to the survey data of geothermal wells in 2015, there are 544 geothermal wells in the Jizhong Depression, accounting for $48.57 \%$ of all geothermal wells in Hebei province [37]. Geothermal wells are mainly distributed in the central uplift zone, while oil wells are mainly distributed in various depressions and slopes in the study area. Figure 1 shows the location of geothermal wells and oil wells.

In the Jizhong Depression, the Cenozoic formations compose of Pinyuan Formation (Qp) of Quaternary; Minghuazhen Formation (Nm) and Guantao Formation (Ng) of Neogene; and Dongying Formation (Ed), Shahejie Formation (Es), and Kongdian Formation (Ek) of Paleogene. These formations are all sedimentary rocks. The formations of the buried hill developed in the Paleozoic and Precambrian, and they are dominated by weathered and denuded carbonate which formed during the Ordovician $(O)$, Cambrian $(E)$, Qingbaikou (Qb), and Jixian (Jx) (Figure 2).
2.2. Hydrogeological Settings. There are three geothermal aquifer systems in the Jizhong Depression: ProterozoicLower Paleozoic weak alternating area, Upper PaleozoicPaleogene hydrodynamic blocking area, and Neogene strong alternating area. The west (Taihang mountain) and the north (Yanshan mountain) are the main water supply area $[38,39]$. The atmospheric precipitation permeated through the basin along with the carbonate aquifer system or the peripheral deep fault belt. Groundwater flowed mainly from the Taihang mountains in the west of the depression to the southeast, just a small amount flowed from the Yanshan mountains in the north of the depression to the southwest, and a minimal amount came from the Cangxian uplift area. After the groundwater in the surrounding mountains crossed the alternating area at the edge of the basin, the flow transformed into a long-distance horizontal (near horizontal) migration. It absorbed heat from surrounding rock, reacted with the rock sufficiently, and dissolved the soluble components of rock. According to the measured water pressure of the buried hill by drilling, it is converted into the distribution of the current water head, and the distribution diagram of it is drawn (Figure 3). In this region, the groundwater head of the buried hill gradually decreases from the basin periphery to the basin center, forming the movement trend of groundwater from the depression periphery to the center, that is, the characteristics of typical "centripetal flow" [38-40].

2.3. Geothermal Regime Settings. The present geothermal gradient in sedimentary basins is studied through various borehole test temperature data [33]. The present geothermal gradient in the Jizhong Depression is $2.8 \sim 3.8^{\circ} \mathrm{C} / 100 \mathrm{~m}$, and the average geothermal gradient is $3.2 \sim 3.4^{\circ} \mathrm{C} / 100 \mathrm{~m}$. In the Beijing-Xushui-Baoding-Shijiazhuang swell belt, which is in the west of the depression, the present geothermal gradient ranges from $2.8^{\circ} \mathrm{C}$ to $3.2^{\circ} \mathrm{C} / 100 \mathrm{~m}$. The ground temperature gradient of the east area, which is the adjacent Niutuo-RongchengGaoyang uplift area increased by $3.6 \sim 3.8^{\circ} \mathrm{C} / 100 \mathrm{~m}$. However, the present geothermal gradient in the three oil-bearing depressions of Langgu, Baxian, and Raoyang in the east of Niutuo town, Rongcheng, and Gaoyang uplift decreases to $3.0 \sim 3.2^{\circ} \mathrm{C} / 100 \mathrm{~m}$. After that, the geothermal gradient in the east increased again, reaching $3.4 \sim 3.6^{\circ} \mathrm{C} / 100 \mathrm{~m}$ in the uplift area of Cangxian county $[4,34]$. The present geothermal gradient distribution in the depression is consistent with the underlying basement structure.

By using the oil test temperature data, a section map of the relationship between formation temperature and formation distribution at $3500 \mathrm{~m}$ was drawn (Figure 4, the position of the section as shown in Figure 1). According to the collected temperature data, the temperature of buried hills at $3500 \mathrm{~m}$ is generally $110 \sim 150^{\circ} \mathrm{C}$, and that of the depression area is relatively lower $\left(110 \sim 124^{\circ} \mathrm{C}\right)$. In the uplift area and the swell area inside the depression area, the ground temperature is significantly increased $\left(127 \sim 148^{\circ} \mathrm{C}\right)$. Figure 4 shows that the temperature of the northwestern uplift area is lower than the eastern uplift area, and the temperature of the convex area of the depression is generally higher than the temperature of the depression at the same depth. 


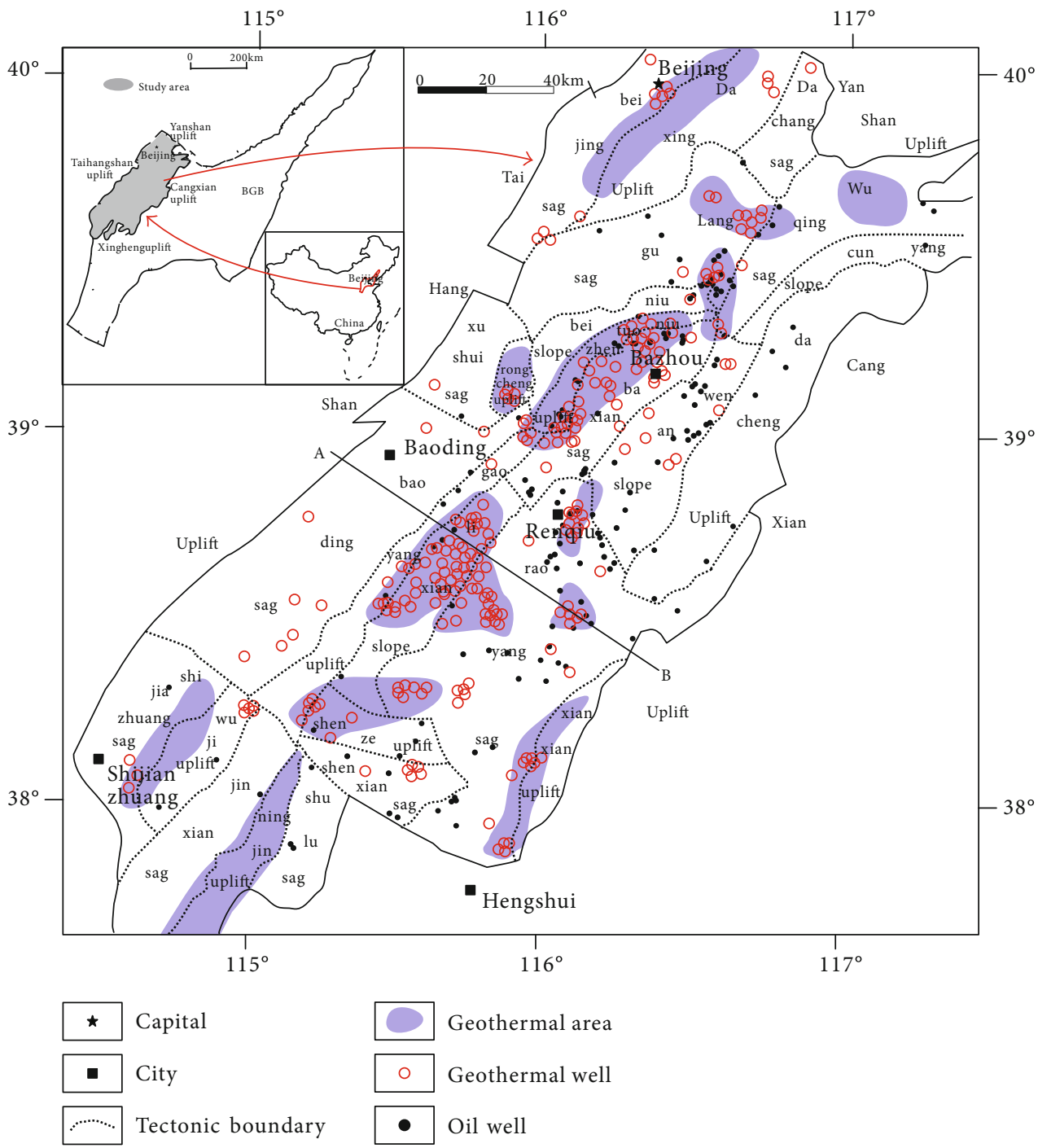

FIGURE 1: Sketch map showing the structure and geothermal area of the Jizhong Depression.

\section{Materials and Methods}

3.1. Sampling and Analysis. The Huabei Oilfield Research Institute provided hydrochemical data from about 400 groundwater samples. Groundwater samples were obtained from drill stem tests (DST) of oil wells [41]. These wells were drilled between 1970 and 2000. And the obtained water samples were tested by oilfield water analysis testing methods (National Standard SY5523-2000). The cation in the water sample is $\mathrm{Na}^{+}, \mathrm{K}^{+}, \mathrm{Ca}^{2+}, \mathrm{Mg}^{2+}$, or $\mathrm{B}^{3+}$, and the anion is $\mathrm{Cl}^{-}$, $\mathrm{HCO}_{3}^{-}, \mathrm{CO}_{3}^{2-}, \mathrm{SO}_{4}^{2-}, \mathrm{Br}^{-}$, or I ${ }^{3-}$.

The collected test results are analyzed to determine whether the test results are accurate. Since a fundamental condition of the electrolytic solution is electrical neutrality, the total number of positive charges carried by the cations in the solution should be equal to the total number of negative charges carried by the anions.

Groundwater is an electrolytic solution with a relatively complex composition. Therefore, groundwater also follows the electrical neutrality equation. The electrical neutrality equation is

$$
\sum Z m_{\mathrm{c}}=\sum Z m_{\mathrm{a}}
$$

In the formula, $m_{\mathrm{a}}$ and $m_{\mathrm{c}}$, respectively, represent the molar concentration of anions and cations, and $Z$ represents the respective charge number of anions and cations.

Although the composition of groundwater is very complicated, there are also differences between major ions and trace elements. Trace elements have little effect on the calculation. Therefore, in the calculation, the trace elements are removed. This article only calculates the electrical neutrality equation of the main ion content.

The components in groundwater are expressed by their constant components. The expression is

$$
\left(\mathrm{Na}^{+}\right)+\left(\mathrm{K}^{+}\right)+2\left(\mathrm{Ca}^{2+}\right)+2\left(\mathrm{Mg}^{2+}\right)=\left(\mathrm{Cl}^{-}\right)+\left(\mathrm{HCO}_{3}^{-}\right)+2\left(\mathrm{SO}_{4}^{2-}\right) .
$$

In this test result, the $\mathrm{B}^{3+}, \mathrm{CO}_{3}^{2-}, \mathrm{Br}^{-}$, and $\mathrm{I}^{3-}$ contents are very small so that these elements can be omitted in this calculation. There are trace components in the test, and there may 

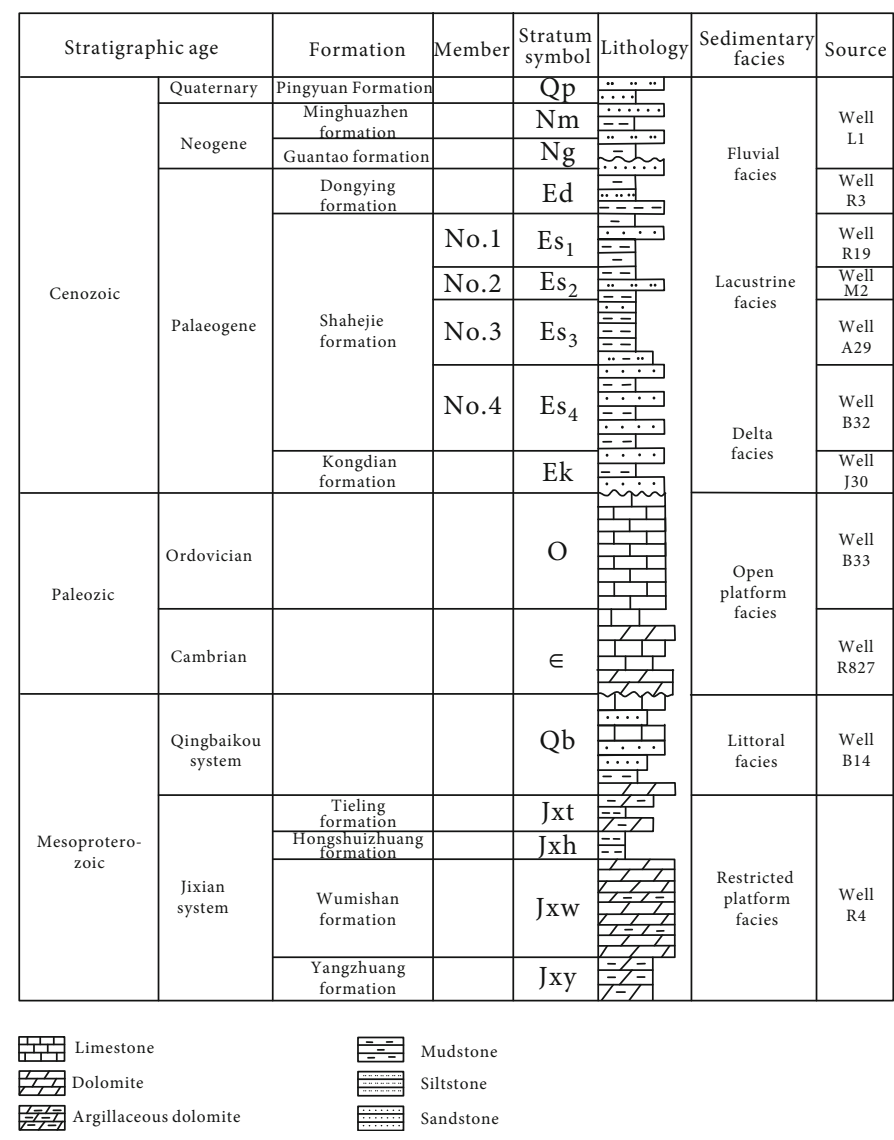

FIGURE 2: Stratigraphic histogram in the study area.

be some errors, but the test results cannot be considered wrong, and the above formula is only an approximate equation. If the test result of the electrical neutral equation is within a certain error range, the test result can be considered correct.

$$
E=\frac{\left(\sum Z m_{\mathrm{c}}-\sum Z m_{\mathrm{a}}\right)}{\left(\sum Z m_{\mathrm{c}}+\sum Z m_{\mathrm{a}}\right)}
$$

$E$ stands for charge balance error (unit: \%).

If the absolute value of the calculated result is less than $5 \%$, the calculated result is reliable; if the absolute value of the calculated result is higher than $5 \%$, the test result is doubtful.

The formula was used to test all collected sample data, and the absolute value of most of the calculated results was found to be less than $5 \%$. The test results of the collected data were credible, indicating that the analysis results were reasonable. In order to ensure the credibility of the data, we exclude the data with a large absolute value.

3.2. Chemical Geothermometer. Chemical geothermometers were applied to estimate the temperatures of the geothermal reservoirs, including three cation geothermometers (the equilibrium constants for exchange and alteration reactions are temperature dependent). Table 1 lists the formulas for the calculations used in this research. Moreover, the equilibrium state between thermal water and specific minerals was studied using the $\mathrm{Na}-\mathrm{K}-\mathrm{Mg}$ triangle diagram [18].

\section{Results and Discussion}

4.1. Hydrochemical Characteristics. The relationship between the total dissolved solids (TDS) and the depth of the geothermal reservoir in the study area is studied. The shallowly buried hill geothermal reservoirs $(500 \sim 1500 \mathrm{~m})$ have the lowest TDS, which is less than $5 \mathrm{~g} / \mathrm{L}$; the middle part of buried hill geothermal reservoirs $(1500 \sim 3000 \mathrm{~m})$ is $2 \sim 15 \mathrm{~g} / \mathrm{L}$; and the deeply buried hill geothermal reservoirs $(3000 \sim 5000 \mathrm{~m})$ are relatively high and have a broader distribution range, ranging from 2 to $45 \mathrm{~g} / \mathrm{L}$. Overall, the TDS increases as the depth of geothermal reservoirs increases (Figure 5).

By using cluster analysis of the main ions of the water samples, the water samples in the study area can be divided into three groups (Figure 6). The anions of group I are mainly $\mathrm{Cl}^{-}$and $\mathrm{HCO}_{3}^{-}$, and the cation is mainly $\mathrm{Na}^{+}$; geothermal water is $\mathrm{Cl} \cdot \mathrm{HCO}_{3}-\mathrm{Na}$ type; and the TDS is relatively low, generally less than $5 \mathrm{~g} / \mathrm{L}$. The average sodium chloride coefficient is 1.34 , the metamorphic coefficient is -9.3 on average, and the desulfurization coefficient is generally higher than 10.0. The anion of group II is mainly $\mathrm{Cl}^{-}$, and the cation is mainly $\mathrm{Na}^{+}$; geothermal water is Cl-Na type; and the TDS is 


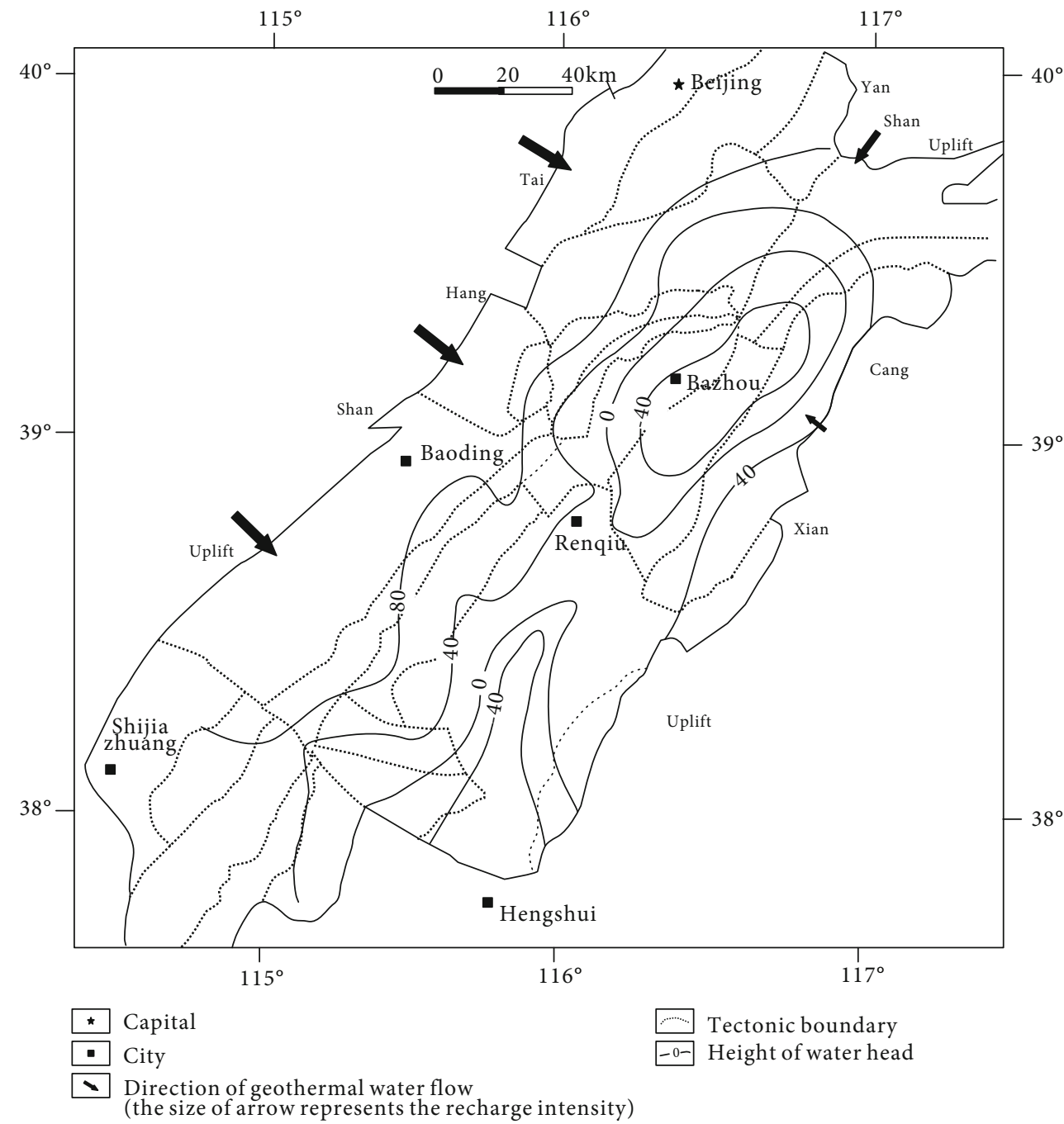

FIgURE 3: Current water head distribution of the geothermal reservoir in the buried hill of the study area.

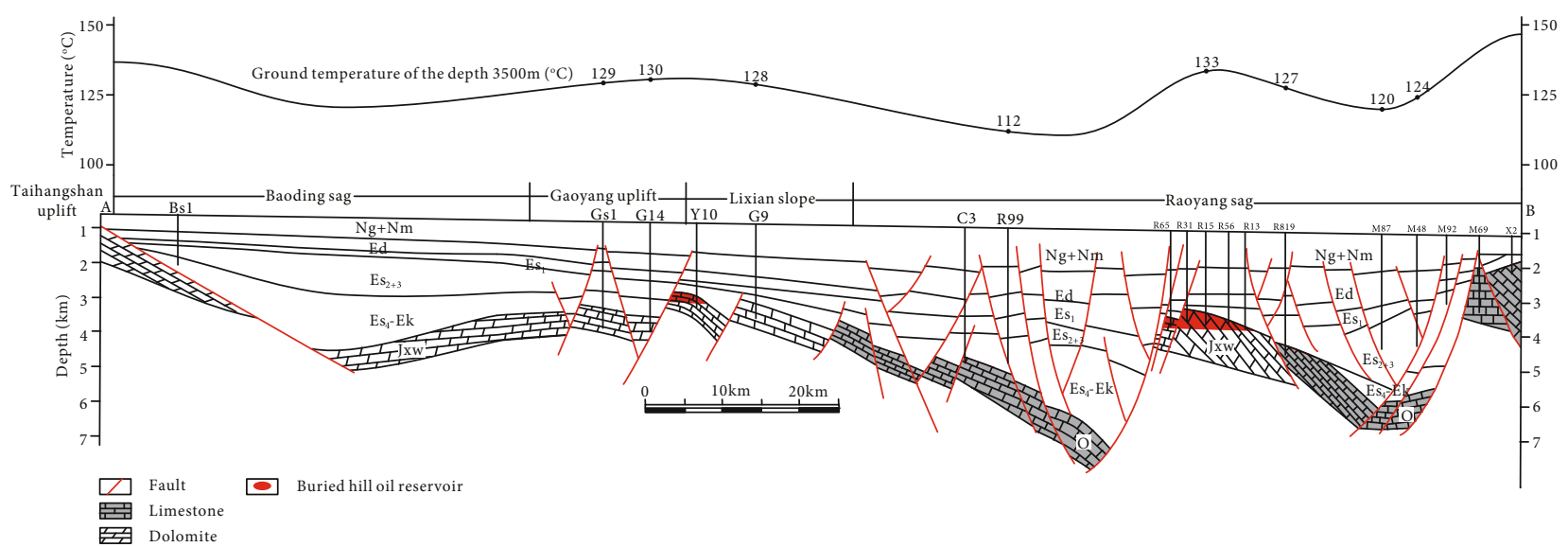

FiguRE 4: Formation (depth $3500 \mathrm{~m}$ ) temperature and stratigraphic distribution in the study area.

higher than group I, generally $5 \sim 20 \mathrm{~g} / \mathrm{L}$. The sodium chloride coefficient is 0.96 on average, the metamorphic coefficient is -3.19 on average, and the desulfurization coefficient is 6.4 on average. The anion of group III is mainly $\mathrm{Cl}^{-}$, and cations are mainly $\mathrm{Na}^{+}$and $\mathrm{Ca}^{2+}$; geothermal water is $\mathrm{Cl}-\mathrm{Na} \cdot \mathrm{Ca}$ type; and the TDS is the highest in all three groups, more than 
TABLE 1: Chemical geothermometers used in this work.

\begin{tabular}{lcr}
\hline Geothermometer & Calibration & Author \\
\hline Na-K & $T_{\mathrm{Na}-\mathrm{K}}=\frac{1390}{1.75+\log (\mathrm{Na} / \mathrm{K})}-273.15$ & Giggenbach (1988) \\
& $T_{\mathrm{Na}-\mathrm{K}}=\frac{1217}{1.483+\log (\mathrm{Na} / \mathrm{K})}-273.15$ & Fournier (1979) \\
$\mathrm{K}-\mathrm{Mg}$ & $T_{\mathrm{K}-\mathrm{Mg}}=\frac{4410}{13.95 \log \left(\mathrm{K}^{2} / \mathrm{Mg}\right)}-273.15$ & Giggenbach et al. (1983) \\
$\mathrm{Na-K-Ca}$ & $T_{\mathrm{Na}-\mathrm{K}-\mathrm{Ca}}=\frac{1647}{\log (\mathrm{Na} / \mathrm{K})+\beta[\log (\sqrt{\mathrm{Ca}} / \mathrm{Na})+2.06]+2.47}-273.15$ & Fournier and Truesdell (1973) \\
\hline
\end{tabular}

Concentration units for the elements involved are all in $\mathrm{mg} / \mathrm{L}$. The empirical coefficient $\beta$ value is determined based on the calculation result. When the calculated temperature is less than $100^{\circ} \mathrm{C}$, the empirical coefficient $\beta$ is $4 / 3$; when the calculated temperature is higher than $100^{\circ} \mathrm{C}$, the empirical coefficient $\beta$ is $1 / 3$.

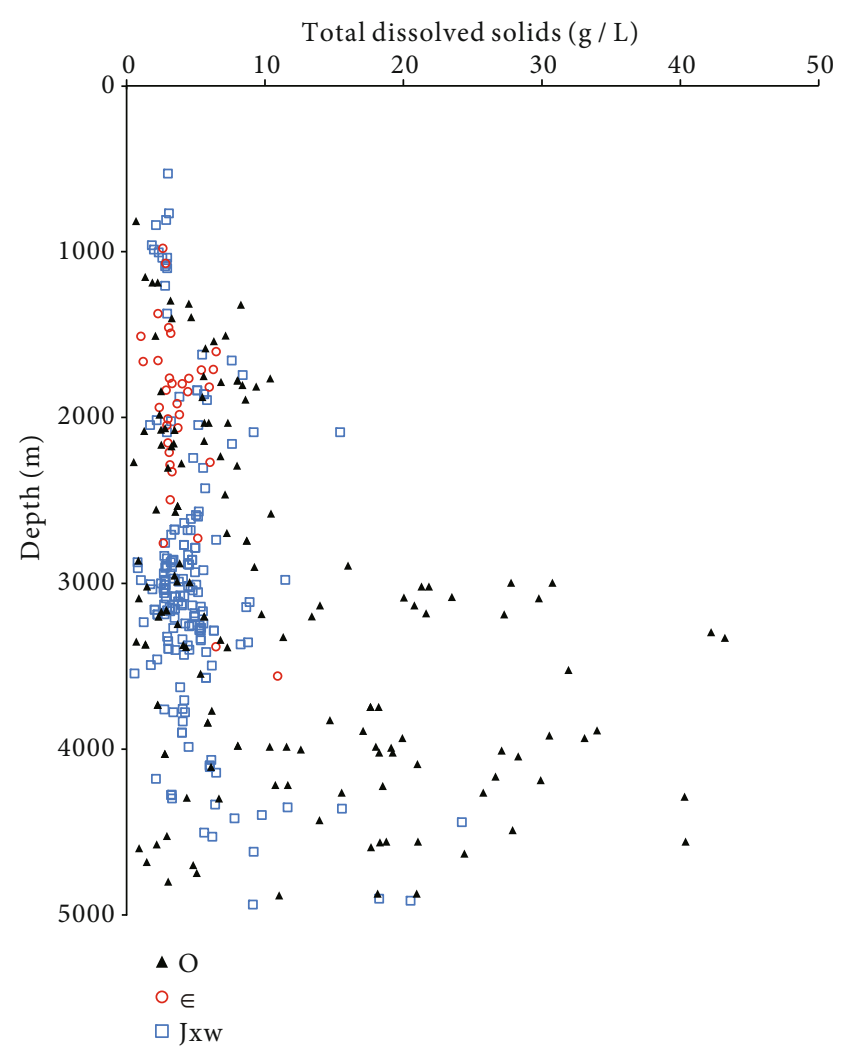

FIGURE 5: Depth and TDS for geothermal water in the study area.

$20 \mathrm{~g} / \mathrm{L}$. The sodium chloride coefficient is 0.61 on average, the metamorphic coefficient is 3.8 on average, and the desulfurization coefficient is generally less than 3.0 (Table 2).

The horizontal distribution of water samples in the study area is studied (Figure 7). Group I geothermal water is mainly distributed in the west and north of the study area, group II geothermal water is mainly distributed in the middle and south of the study area, and group III geothermal water is distributed in the eastern Bazhou, within a small area in the north of Hengshui.

Comparing the current water head distribution map (Figure 3) with the buried hill geothermal water distribution map (Figure 7), it is found that there is a good correspondence between the types of geothermal water and the "centripetal flow" feature in the hydrological characteristics.

The samples were classified into three groups by using cluster analysis, and the hydrochemical characteristics of each group were also compared and analyzed. The sealing of geothermal water has also been studied, mainly considering three types of parameters, which were the sodium chloride coefficient $\left(r\left(\mathrm{Na}^{+}\right) / r\left(\mathrm{Cl}^{-}\right)\right)$, metamorphic coefficient $\left(r\left(\mathrm{Cl}^{-}-\mathrm{Na}^{+}\right) / r\left(\mathrm{Mg}^{2+}\right)\right)$, and desulfurization coefficient $\left(r\left(\mathrm{SO}_{4}^{2-}\right) \times 100 / r\left(\mathrm{Cl}^{-}\right)\right)$.

The sodium chloride coefficient is a parameter that reflects the degree of groundwater concentration and deterioration. The chemical properties of chloride ions in this coefficient are stable, and there is a little reflection of adsorption, precipitation, and exchange, while sodium ions may decrease due to chemical reactions such as adsorption and precipitation. From the perspective of sedimentology, the sodium chloride coefficient of water in marine formations is relatively small, the sodium chloride coefficient of land is relatively large, and the sodium chloride coefficient of salt lakes is close to 1 . From the perspective of water concentration and deterioration, the higher the concentration or deterioration, the lower the sodium chloride coefficient [42].

The desulfurization coefficient is an important parameter reflecting the degree of desulfurization and the reduction of groundwater. Chlorine ion and sulfate ion are the two anions with the highest content in groundwater. Due to the differences in the extensiveness and stability of the two ion sources, the content of sulfate is usually not as high as that of chloride ion. In the groundwater, sulfate ions mainly come from the dissolution of gypsum $\left(\mathrm{CaSO}_{4} \cdot 2 \mathrm{H}_{2} \mathrm{O}\right)$ or other sulfate rocks, and sulfur, which is originally insoluble in water, enters the groundwater in large quantities through the oxidation of sulfides. On the other hand, in the reducing environment, when there is organic matter, the desulfurization bacteria can reduce $\mathrm{SO}_{4}^{2-}$ to $\mathrm{H}_{2} \mathrm{~S}$. Therefore, the higher the degree of formation closure, the lesser the external sulfate supply and the stronger the degree of sulfate reduction, resulting in a smaller desulfurization coefficient in the groundwater. However, when there are gypsum salts, coal measures, and metal 


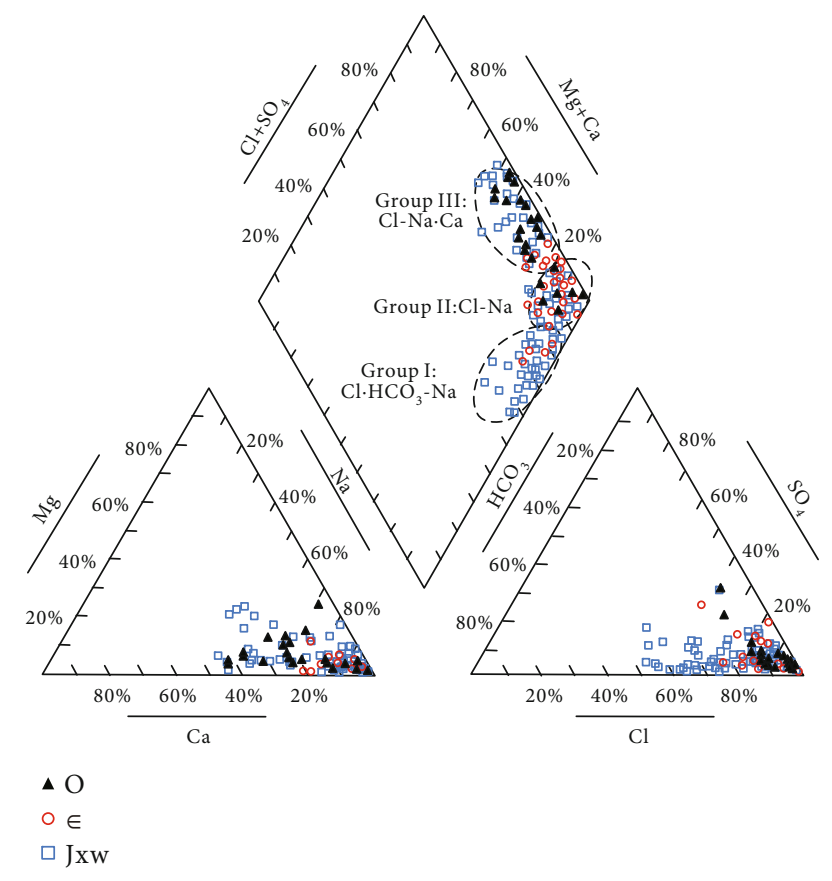

Figure 6: Piper diagram of geothermal water in the buried hill of the study area.

sulfide deposits in the local formation, the sulfate content abnormally increases, leading to a significant increase in the desulfurization coefficient [42].

The metamorphic coefficient reflects the degree of ion exchange during the migration of formation water. In a closed environment, the content of unstable ions in groundwater tends to decrease, while the relative content of ions with high stability continues to increase. The main reason for the change in the relative content of groundwater ions is the ion exchange effect. Under this effect, the anions that are less stable (e.g., $\mathrm{CO}_{3}^{2-}$ and $\mathrm{HCO}_{3}^{-}$) are reduced first, leaving more stable chloride ions. After that, the cations exchanged, and the highly active magnesium ions were replaced by the more stable calcium ions. The metamorphic coefficient can be used to characterize the metamorphic process. The greater the burial depth, the better the sealing conditions and the longer the continuous geological time. In general, the longer the time of water-rock interaction, the more ion exchange will be and the higher the deterioration coefficient becomes $[26,42]$.

Figure 5 indicates that the TDS of the geothermal water increases with the increase of depth. From group I to group III, the TDS of the geothermal water also shows an increasing trend. Studying the relationship between TDS and three types of coefficients (sodium chloride coefficient, desulfurization coefficient, and metamorphic coefficient), it is found that the sodium chloride coefficient and the desulfurization coefficient are gradually decreasing, and the metamorphic coefficient is gradually increasing, which indicates that with the increase of depth, the reduction of the three groups (from group I to group III) is getting better, and water-rock interaction is getting stronger (Figure 8).

\subsection{Temperatures of Geothermal Reservoirs}

4.2.1. Geothermometric Applications. The water-rock equilibrium state should be judged before applying cation geothermometers. The cation geothermometers based on the equilibrium of $\mathrm{Na}-\mathrm{K}, \mathrm{Na}-\mathrm{K}-\mathrm{Ca}$, and $\mathrm{K}-\mathrm{Mg}$ are widely used to evaluate the geothermal reservoir temperature. Sometimes the temperature calculated by the cation geothermometers has a significant deviation from the actual temperature. The main problem is the use of unreasonable water samples. It is relatively difficult to use $\mathrm{pH}$ and concentrations such as $\mathrm{Cl}^{-}$, $\mathrm{SO}_{4}^{2-}$, and $\mathrm{HCO}_{3}^{-}$to eliminate inappropriate water samples. Giggenbach first proposed the $\mathrm{Na}-\mathrm{K}-\mathrm{Mg}$ triangle diagram to evaluate the water-rock equilibrium state and distinguish three different types (immature water, partially equilibrated water, and fully equilibrated water) of water samples. The distribution in the figure can be used to determine whether the minerals in the geothermal water have reached saturation and whether geothermal water is suitable for cation geothermometers. Fully equilibrated water means that the dissolved minerals in the geothermal water and the surrounding rock have reached the equilibrium state. At this time, the results calculated according to the $\mathrm{Na}-\mathrm{K}$ geothermometer and the $\mathrm{K}-\mathrm{Mg}$ geothermometer are equal, and the results should be located at the intersection of partially equilibrated water and fully equilibrated water scales in the $\mathrm{Na}-\mathrm{K}-\mathrm{Mg}$ triangle diagram [18, 43-45].

The $\mathrm{Na}, \mathrm{K}$, and $\mathrm{Mg}$ ion contents of the buried hill geothermal water collected in the study area are projected into the Na-K-Mg triangle diagram (Figure 9). The geothermal water sample of group I is close to the $\mathrm{Mg}$ end-member in the lower right corner, and it belongs to immature water. The result reflects that the sodium and potassium minerals in the geothermal water is not saturated. In principle, it is unreasonable to estimate the equilibrium temperature by using these immature water samples. The geothermal water point of group I fits into a dilution line, and the intersection point with the fully equilibrated water line is the temperature at which the geothermal water reaches equilibrium, which is approximately $173^{\circ} \mathrm{C}$. It indicates that geothermal water is mixed with cold water in the shallow strata so that the dissolved equilibrium water is affected by cold water and became immature water. The geothermal water samples of group II and group III are located in the partially equilibrated water zone, indicating that they mix less with cold water, which is partially equilibrated water, and the temperature can be estimated by cation geothermometers.

4.2.2. Cation Geothermometer. The cation geothermometer is used to estimate the heat exchange temperature of the deep buried hill geothermal system in the Jizhong Depression. Table 3 shows the calculation results. For the same geothermal water system, the calculation obtained with different geothermometers is quite different. Therefore, it is necessary to discuss the applicability of various temperature scales with the measured data.

The temperature of geothermal reservoirs calculated by the $\mathrm{Na}-\mathrm{K}$ geothermometer is higher than that by the $\mathrm{K}-\mathrm{Mg}$ geothermometer. For temperature changes, the chemical reaction of the $\mathrm{K}-\mathrm{Mg}$ geothermometer reaches the equilibrium 
TABLE 2: Geochemical characteristics of geothermal water in the buried hill of the study area.

\begin{tabular}{|c|c|c|c|c|c|c|c|}
\hline \multirow[b]{2}{*}{ Group } & \multirow{2}{*}{$\begin{array}{l}\text { TDS } \\
(\mathrm{g} / \mathrm{L})\end{array}$} & \multicolumn{2}{|c|}{ Hydrochemical type } & \multirow{2}{*}{$\begin{array}{l}\text { Main cation and anion } \\
\text { (percentage of meq) }\end{array}$} & \multicolumn{3}{|c|}{ Ionic ratio ( Min $\sim$ Max/average) } \\
\hline & & $\begin{array}{c}\text { Surin } \\
\text { classification }\end{array}$ & $\begin{array}{c}\text { Shu kraft } \\
\text { classification }\end{array}$ & & $r\left(\mathrm{Na}^{+}\right) / r\left(\mathrm{Cl}^{-}\right)$ & $r\left(\mathrm{Cl}^{-}-\mathrm{Na}^{+}\right) / r\left(\mathrm{Mg}^{2+}\right)$ & $r\left(\mathrm{SO}_{4}^{2-}\right) \times 100 / r\left(\mathrm{Cl}^{-}\right)$ \\
\hline I & $<5$ & $\mathrm{NaHCO}_{3}$ & $\mathrm{Cl} \cdot \mathrm{HCO}_{3}-\mathrm{Na}$ & $\begin{array}{c}\mathrm{Cl}^{-}(52 \%) \\
\mathrm{HCO}_{3}^{-}(37 \%) \\
\mathrm{Na}^{+}(83 \%)\end{array}$ & $\frac{1.21 \sim 2.51}{1.34}$ & $\frac{-45.9 \sim 9.6}{-9.3}$ & $\frac{8.1 \sim 48.1}{14.4}$ \\
\hline II & $5 \sim 20$ & $\begin{array}{l}\mathrm{NaHCO}_{3} \\
\text { and } \mathrm{CaCl}_{2}\end{array}$ & $\mathrm{Cl}-\mathrm{Na}$ & $\begin{array}{l}\mathrm{Cl}^{-}(92 \%) \\
\mathrm{Na}^{+}(90 \%)\end{array}$ & $\frac{0.81 \sim 1.11}{0.96}$ & $\frac{-30.4 \sim 12.5}{-3.2}$ & $\frac{1.4 \sim 13.3}{6.4}$ \\
\hline III & $>20$ & $\mathrm{CaCl}_{2}$ & $\mathrm{Cl}-\mathrm{Na} \cdot \mathrm{Ca}$ & $\begin{array}{l}\mathrm{Cl}^{-}(89 \%) \\
\mathrm{Na}^{+}(58 \%) \\
\mathrm{Ca}^{2+}(30 \%)\end{array}$ & $\frac{0.32 \sim 1.05}{0.61}$ & $\frac{-9.3 \sim 16.2}{3.8}$ & $\frac{0.3 \sim 3.4}{2.6}$ \\
\hline
\end{tabular}

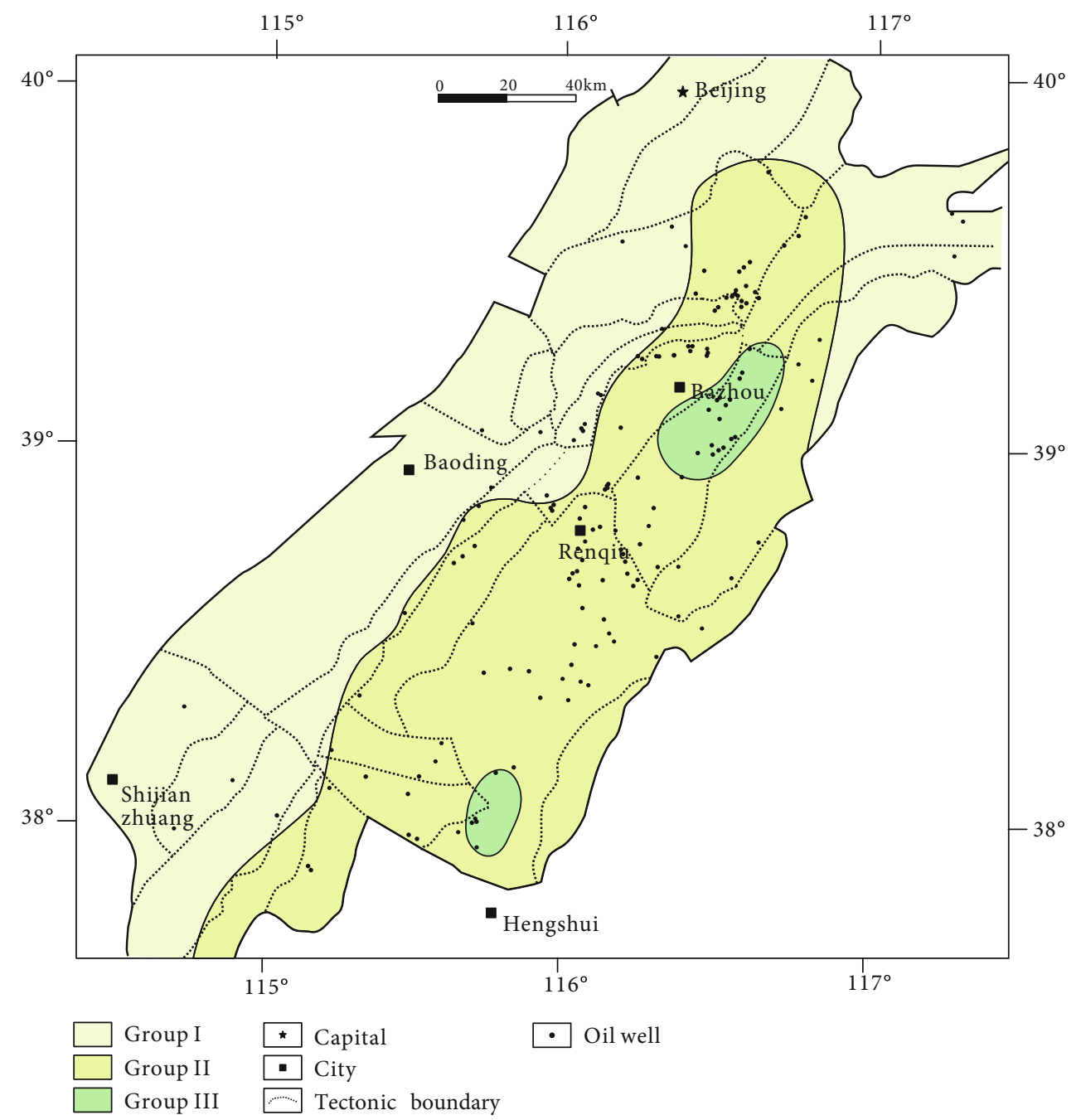

FIgURE 7: Three different types of buried hill geothermal water in the study area.

faster than that of the $\mathrm{Na}-\mathrm{K}$ geothermometer, even at low temperatures. The equilibrium of the $\mathrm{K}-\mathrm{Mg}$ geothermometer is continuously broken and rebalanced by the conduction cooling or the mixing with the shallow cold water during the process of rising water from the deep to the surface so that the $\mathrm{K}-\mathrm{Mg}$ geothermometer calculation results are biased toward the shallow heat exchange temperature and the drilling temperature. In general, the geothermal system in the study area has a multistage geothermal reservoir. During the processes from a deep geothermal reservoir to a shallow geothermal reservoir, the geothermal water reestablishes a new waterrock equilibrium state. In this process, the equilibrium state of $\mathrm{Na}^{+} / \mathrm{K}^{+}$changes slower, which is consistent with the deep geothermal reservoir, while the equilibrium state of $\mathrm{K}^{+} / \mathrm{Mg}^{2+}$ 


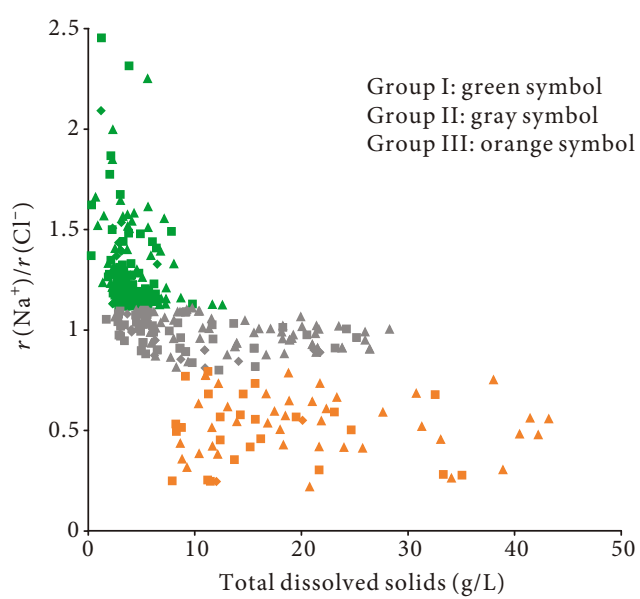

(a)

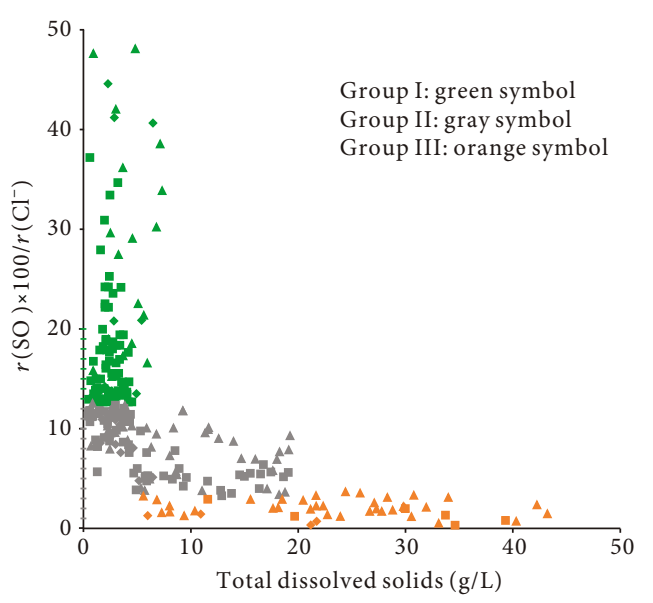

(b)

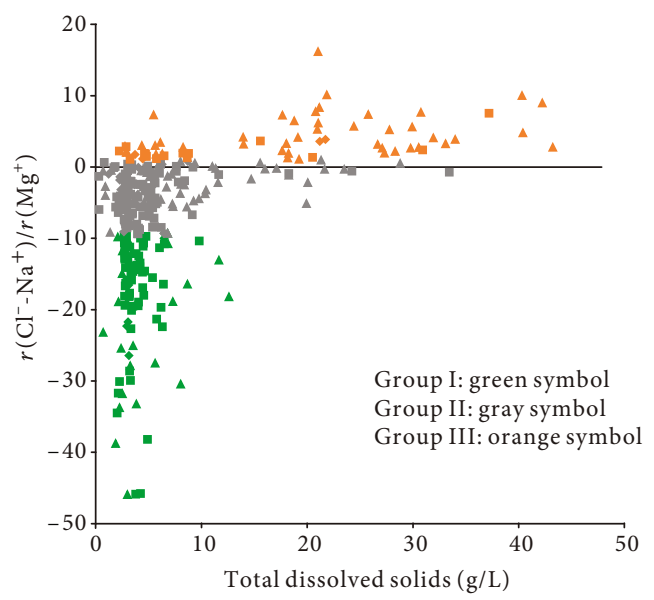

(c)

FIGURE 8: Relationship between TDS and three coefficients of the geothermal water in the study area. (a) Sodium chloride coefficient. (b) Desulfurization coefficient. (c) Metamorphic coefficient. Triangle: Ordovician samples. Diamond: Cambrian samples. Square: Jixian samples.

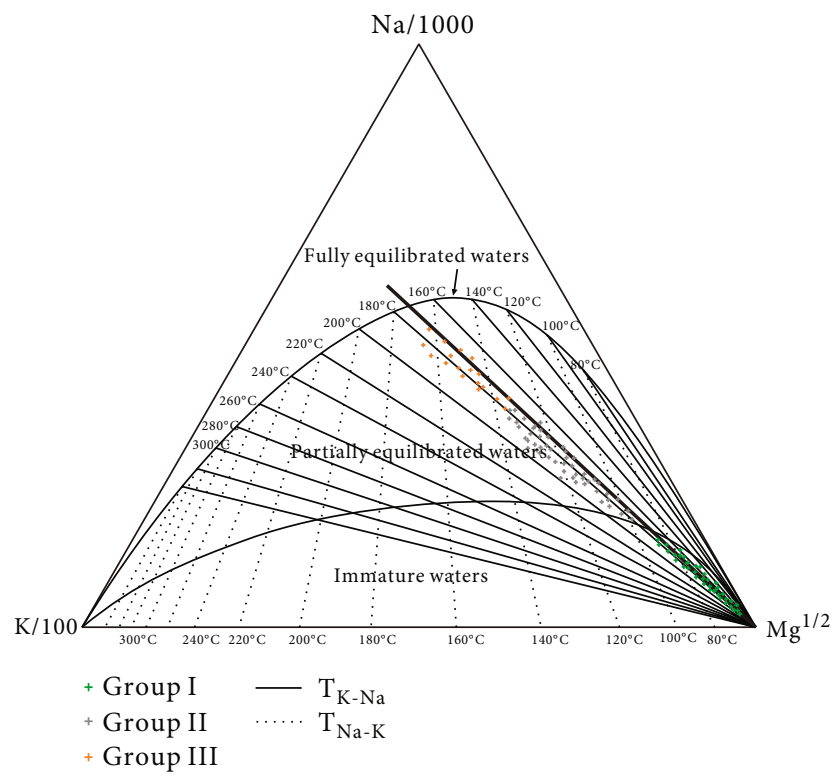

Figure 9: $\mathrm{Na}-\mathrm{K}-\mathrm{Mg}$ triangle diagram of the geothermal water in the buried hill of the study area. changes faster, and the water-rock equilibrium state is reestablished in the shallow geothermal reservoir. Therefore, in the water samples, the equilibrium state of $\mathrm{Na}^{+} / \mathrm{K}^{+}$is close to the deep geothermal reservoir, and the equilibrium state of $\mathrm{K}^{+} / \mathrm{Mg}^{2+}$ is close to the shallow geothermal reservoir. So the $\mathrm{Na}-\mathrm{K}$ geothermometer is suitable for calculating the deep geothermal reservoir, and the $\mathrm{K}-\mathrm{Mg}$ geothermometer is suitable for calculating the shallow geothermal reservoir. Based on the calculation results of the $\mathrm{K}-\mathrm{Mg}$ geothermometer, the ranges of the shallow strata are $91 \sim 146^{\circ} \mathrm{C}$. And based on the calculation results of the $\mathrm{Na}-\mathrm{K}$ geothermometer, the ranges of the deep strata are $147 \sim 176^{\circ} \mathrm{C}$.

As shown in Table 3, the temperature calculated by the $\mathrm{K}-\mathrm{Mg}$ geothermometer $\left(T_{\mathrm{K}-\mathrm{Mg}}\right.$; the temperature calculated by the Na-K geothermometer is $T_{\mathrm{Na}-\mathrm{K}}$, and the temperature calculated by the Na-K-Ca geothermometer is $T_{\mathrm{Na}-\mathrm{K}-\mathrm{Ca}}$ ) is closer to the observed temperature, which reflects that the equilibrium state of the $\mathrm{K}-\mathrm{Mg}$ is continuously broken and rebalanced during the upward movement of the deep geothermal water. So the calculation is closer to the temperature of the shallow geothermal water. As mentioned earlier, 
TABLE 3: Observed temperature and the calculation results of geothermal reservoirs.

\begin{tabular}{|c|c|c|c|c|c|c|c|}
\hline Well & Depth (m) & Group & $\mathrm{Na}-\mathrm{K}$ & $\mathrm{K}-\mathrm{Mg}$ & $\begin{array}{c}\text { Geothermometer }\left({ }^{\circ} \mathrm{C}\right) \\
\text { Na-K-Ca }(\beta=4 / 3)\end{array}$ & $\mathrm{Na}-\mathrm{K}-\mathrm{Ca}(\beta=1 / 3)$ & Observed temperature $\left({ }^{\circ} \mathrm{C}\right)$ \\
\hline B5 & 2164 & II & 157.0 & 120.1 & 162.8 & 158.9 & 101 \\
\hline B9 & 1938 & II & 149.8 & 98.1 & 202.1 & 165.1 & 98 \\
\hline B10 & 1763 & II & 163.3 & 111.8 & 207.5 & 173.7 & 92 \\
\hline B12 & 1891 & II & 170.2 & 131.4 & 219.5 & 180.0 & 98 \\
\hline B13 & 2567 & II & 160.0 & 126.5 & 211.3 & 172.3 & 106 \\
\hline B14 & 1796 & II & 160.5 & 97.6 & 259.4 & 183.6 & 92 \\
\hline B17 & 2008 & II & 156.6 & 111.8 & 229.8 & 176.4 & 100 \\
\hline B21 & 3544 & III & 166.2 & 163.1 & 212.8 & 176.3 & 133 \\
\hline B24 & 2496 & II & 156.7 & 105.2 & 205.8 & 169.9 & 103 \\
\hline L13 & 2158 & II & 169.2 & 126.9 & 183.2 & 170.2 & 102 \\
\hline L16 & 1743 & II & 170.0 & 127.4 & 219.5 & 180.0 & 90 \\
\hline L23 & 3242 & III & 163.6 & 145.0 & 223.2 & 176.9 & 122 \\
\hline L24 & 3270 & III & 175.9 & 120.0 & 212.8 & 176.3 & 123 \\
\hline L25 & 3282 & III & 165.8 & 118.2 & 191.7 & 171.1 & 122 \\
\hline M10 & 1894 & II & 145.9 & 113.9 & 267.2 & 187.4 & 94 \\
\hline M14 & 1709 & II & 155.6 & 91.6 & 142.0 & 158.7 & 89 \\
\hline M15 & 2728 & II & 165.2 & 116.0 & 188.3 & 170.3 & 110 \\
\hline M17 & 2566 & II & 165.5 & 114.9 & 200.8 & 173.4 & 104 \\
\hline M23 & 2244 & II & 164.3 & 106.8 & 121.4 & 149.8 & 104 \\
\hline M25 & 3760 & III & 174.6 & 105.6 & 185.2 & 163.2 & 142 \\
\hline N19 & 2878 & II & 160.5 & 123.7 & 203.3 & 170.9 & 107 \\
\hline $\mathrm{R} 4$ & 3152 & II & 159.7 & 125.4 & 181.3 & 164.7 & 113 \\
\hline R6 & 3414 & III & 167.1 & 138.0 & 247.2 & 183.7 & 130 \\
\hline R7 & 3072 & II & 161.6 & 116.8 & 228.7 & 177.1 & 110 \\
\hline $\mathrm{R} 8$ & 3400 & III & 164.2 & 133.1 & 213.0 & 175.1 & 126 \\
\hline R11 & 2636 & II & 162.6 & 121.7 & 209.2 & 173.5 & 105 \\
\hline R16 & 3186 & II & 154.2 & 113.4 & 174.2 & 160.6 & 112 \\
\hline R17 & 3168 & II & 157.7 & 122.2 & 192.8 & 166.9 & 111 \\
\hline $\mathrm{R} 23$ & 3626 & III & 161.9 & 123.6 & 199.2 & 170.6 & 137 \\
\hline R26 & 3140 & II & 149.2 & 128.7 & 187.3 & 170.2 & 112 \\
\hline R29 & 3284 & II & 167.9 & 139.3 & 176.7 & 168.3 & 118 \\
\hline R31 & 3337 & III & 163.0 & 127.9 & 259.4 & 183.6 & 124 \\
\hline R32 & 3145 & II & 157.4 & 110.3 & 203.5 & 168.9 & 113 \\
\hline R34 & 3123 & II & 162.0 & 118.1 & 153.5 & 159.2 & 113 \\
\hline R35 & 3078 & II & 159.7 & 115.5 & 203.7 & 170.4 & 110 \\
\hline R81 & 3244 & II & 159.8 & 132.0 & 246.8 & 179.5 & 115 \\
\hline R83 & 3370 & III & 161.9 & 110.7 & 206.3 & 172.8 & 121 \\
\hline R841 & 3410 & III & 220.0 & 174.0 & 164.0 & 126.0 & 122 \\
\hline S3 & 3985 & III & 171.8 & 127.7 & 213.8 & 179.7 & 131 \\
\hline S13 & 3185 & II & 171.0 & 126.9 & 235.3 & 183.7 & 114 \\
\hline Y1 & 3054 & II & 154.1 & 112.0 & 173.4 & 160.4 & 111 \\
\hline Y5 & 3089 & II & 155.2 & 146.6 & 176.5 & 161.8 & 114 \\
\hline Y6 & 2163 & II & 141.2 & 119.1 & 171.1 & 159.5 & 102 \\
\hline Y8 & 2302 & II & 156.5 & 128.0 & 167.2 & 159.9 & 106 \\
\hline Y11 & 2063 & II & 153.8 & 107.2 & 160.5 & 157.2 & 100 \\
\hline Y13 & 2031 & II & 165.6 & 124.3 & 180.0 & 168.7 & 99 \\
\hline Y14 & 1507 & II & 148.0 & 105.4 & 157.4 & 151.6 & 86 \\
\hline Y15 & 3347 & III & 160.6 & 127.6 & 229.8 & 176.4 & 120 \\
\hline
\end{tabular}


TABLE 3: Continued.

\begin{tabular}{lccccccc}
\hline Well & Depth $(\mathrm{m})$ & Group & Na-K & K-Mg & $\begin{array}{c}\text { Geothermometer }\left({ }^{\circ} \mathrm{C}\right) \\
\text { Na-K-Ca }(\beta=4 / 3)\end{array}$ & Na-K-Ca $(\beta=1 / 3)$ & Observed temperature $\left({ }^{\circ} \mathrm{C}\right)$ \\
\hline Y18 & 3187 & II & 174.8 & 146.1 & 233.8 & 185.6 & 114 \\
Y19 & 1840 & II & 147.9 & 92.9 & 127.1 & 145.6 & 93 \\
Y20 & 3522 & III & 175.1 & 150.0 & 147.8 & 164.6 & 134 \\
\hline
\end{tabular}

when the dissolved minerals in the geothermal water and the surrounding rock are close to the equilibrium state, the position of the sample point in the $\mathrm{Na}-\mathrm{K}-\mathrm{Mg}$ triangle diagram is closer to the fully equilibrated water line. For example, $T_{\mathrm{K}-\mathrm{Mg}}$ of well B21 $\left(163.1^{\circ} \mathrm{C}\right)$ is close to $T_{\mathrm{Na}-\mathrm{K}}\left(166.2^{\circ} \mathrm{C}\right)$. It is reflected that in the process of the geothermal water rising from the deep to the surface, there is little cold water mixed or nearly adiabatic cooling, and ion exchange is infrequent. In the areas with high $\mathrm{Ca}$ ion concentration, the results of $T_{\mathrm{K}-\mathrm{Mg}}$ and $T_{\mathrm{Na}-\mathrm{K}}$ are abnormal. For example, the $\mathrm{Ca}$ ion concentration reached $1172.3 \mathrm{mg} / \mathrm{L}$ in the water sample of well R841, and the results of $T_{\mathrm{K}-\mathrm{Mg}}\left(174.0^{\circ} \mathrm{C}\right)$ and $T_{\mathrm{Na}-\mathrm{K}}\left(220.0^{\circ} \mathrm{C}\right)$ are abnormal. In this case, the Na-K-Ca geothermometer is suitable. The calculation result was $126.0^{\circ} \mathrm{C}$. Since the observed temperature of the water sample in this study is higher than $100^{\circ} \mathrm{C}$ and the Na$\mathrm{K}$-Ca geothermometer $(\beta=4 / 3)$ is generally used to calculate geothermal water with a temperature less than $100^{\circ} \mathrm{C}$, the calculation results are generally abnormal.

According to drilling data, with overlying sandstone strata, well R8 is a buried hill thermal reservoir of the dolomite at a depth of $3400 \mathrm{~m}$. Well L23 is a buried hill thermal reservoir of the dolomite at a depth of $3242 \mathrm{~m}$, and the overlying strata are conglomerate. Other wells in the study area have similar characteristics. The calculation results are approximate to the observed temperature, which may be attributed to the presence of detrital rocks (silicate minerals) in the buried hill reservoir.

\section{Conclusions}

In this study, all the samples were divided into three groups using cluster analysis of the major elements. The anions of group I are mainly $\mathrm{Cl}^{-}$and $\mathrm{HCO}_{3}^{-}$, and the cation is mainly $\mathrm{Na}^{+}$; the geothermal water is $\mathrm{Cl} \cdot \mathrm{HCO}_{3}-\mathrm{Na}$ type; and the TDS is less than $5 \mathrm{~g} / \mathrm{L}$. The anion of group II is mainly $\mathrm{Cl}^{-}$, and the cation is mainly $\mathrm{Na}^{+}$; the geothermal water is $\mathrm{Cl}$ $\mathrm{Na}$ type; and the TDS is $5 \sim 20 \mathrm{~g} / \mathrm{L}$. The anion of group III is mainly $\mathrm{Cl}^{-}$, and cations are mainly $\mathrm{Na}^{+}$and $\mathrm{Ca}^{2+}$; the geothermal water is $\mathrm{Cl}-\mathrm{Na} \cdot \mathrm{Ca}$ type; and the TDS is more than $20 \mathrm{~g} / \mathrm{L}$.

It is found that the sodium chloride coefficient and the desulfurization coefficient are gradually decreasing and the metamorphic coefficient is gradually increasing, which indicates that with the increase of depth, the reduction of the three groups (from group I to group III) is getting better, and water-rock interaction is getting stronger.

Using the $\mathrm{Na}-\mathrm{K}-\mathrm{Mg}$ triangle diagram, it is found that group I is immature water, group II and group III are partially equilibrated water, and the latter two groups can use cation geothermometers to evaluate geothermal temperature. There are differences in the calculation results of different water geothermometers for the same water sample. The $\mathrm{Na}-\mathrm{K}$ geothermometer is suitable for calculating the deep geothermal reservoir, and the $\mathrm{K}-\mathrm{Mg}$ geothermometer is suitable for calculating the shallow geothermal reservoir. In the areas with high $\mathrm{Ca}$ ion concentration, the $\mathrm{Na}-\mathrm{K}-\mathrm{Ca}$ geothermometer is suitable. Based on the calculation results of the K-Mg geothermometer, the ranges of the shallow strata are $91 \sim 146^{\circ} \mathrm{C}$. And based on the calculation results of the $\mathrm{Na}$ $\mathrm{K}$ geothermometer, the ranges of the deep strata are $147 \sim 176^{\circ} \mathrm{C}$.

It has the good results obtained with some cation geothermometers, such as the $\mathrm{Na}-\mathrm{K}$ geothermometer, in a geothermal system hosted in carbonate rocks like the studied area. This unusual situation may be attributed to the presence of detrital rocks (silicate minerals) in the carbonate reservoir of the buried hill.

At present, in Huabei Oilfield, some abandoned oil wells have been retrofitted, which uses recharge wells to recharge water into geothermal reservoirs and geothermal wells to extract hot water to develop geothermal energy. Studying geochemical characteristics of geothermal water reservoirs will help to select the water injected into the formation, which will protect the reservoir during water injection and production and prevent wellbore corrosion. At the same time, due to the early drilling time of many wells in the study area and the lack of geothermal data or inaccurate data in some wells, the research in this paper can be used to estimate the temperature of deep reservoirs in the study area and provide reference for the development of geothermal resources.

\section{Data Availability}

Readers can obtain the relevant data from the Huabei Oilfield Research Institute.

\section{Conflicts of Interest}

The authors declare that they have no conflicts of interest.

\section{Acknowledgments}

This study was financially supported by the National Science and Technology Special Grant (No. 2016ZX05006-001). Thanks are also given to Huabei Oilfield Company of PetroChina, which provided all the related dates of the Jizhong Depression. 


\section{References}

[1] J. Zhu, K. Hu, X. Lu, X. Huang, K. Liu, and X. Wu, “A review of geothermal energy resources, development, and applications in China: current status and prospects," Energy, vol. 93, pp. 466-483, 2015.

[2] S. J. Wang, J. H. Yan, M. Li, K. W. Li, and S. B. Hu, "New advances in the study of oilfield geothermal resources evaluation," Chinese Journal of Geology, vol. 49, pp. 771-780, 2014.

[3] E. Barbier, "Geothermal energy technology and current status: an overview," Renewable and Sustainable Energy Reviews, vol. 6, no. 1-2, pp. 3-65, 2002.

[4] H. B. Liang, Z. Qian, S. L. Xin, K. J. Zhao, and L. R. Zhu, "Assessment and development of geothermal resources in Jizhong depression," China Petroleum Exploration, vol. 15, no. 5, pp. 63-68, 2010.

[5] J. Y. Wang, N. S. Qiu, S. B. HU, and L. J. He, "Advancement and developmental trend in the geothermics of oil fields in China," Earth Science Frontiers, vol. 24, pp. 1-12, 2017.

[6] T. Kujawa, W. Nowak, and A. A. Stachel, "Analysis of the exploitation of existing deep production wells for acquiring geothermal energy," Journal of Engineering Physics and Thermophysics, vol. 78, no. 1, pp. 127-135, 2005.

[7] T. Kujawa, W. Nowak, and A. A. Stachel, "Utilization of existing deep geological wells for acquisitions of geothermal energy," Energy, vol. 31, no. 5, pp. 650-664, 2006.

[8] A. P. Davis and E. E. Michaelides, "Geothermal power production from abandoned oil wells," Energy, vol. 34, no. 7, pp. 866872, 2009.

[9] W. L. Cheng, T. T. Li, Y. L. Nian, and C. L. Wang, "Studies on geothermal power generation using abandoned oil wells," Energy, vol. 59, pp. 248-254, 2013.

[10] J. D. Templeton, S. A. Ghoreishi-Madiseh, F. Hassani, and M. J. Al-Khawaja, "Abandoned petroleum wells as sustainable sources of geothermal energy," Energy, vol. 70, pp. 366-373, 2014.

[11] Y. L. Nian and W. L. Cheng, "Insights into geothermal utilization of abandoned oil and gas wells," Renewable and Sustainable Energy Reviews, vol. 87, pp. 44-60, 2018.

[12] Y. Z. Wei, F. Q. Wang, and B. Y. Ren, "Drainage and production by using geothermal in Huabei oil region," Oil Drilling \& Production Technology, vol. 31, pp. 93-95, 2009.

[13] Q. S. Dong, X. L. Huang, Z. H. Lang, and Z. Y. Yang, "Technical analysis on transforming abandoned oil well into geothermal well," Exploration Engineering, vol. 43, pp. 18-21, 2016.

[14] R. O. Fournier, "Chemical geothermometers and mixing models for geothermal systems," Geothermics, vol. 5, no. 1-4, pp. 41-50, 1977.

[15] R. O. Fournier, "Geochemical and hydrologic considerations and the use of enthalpy-chloride diagrams in the prediction of underground conditions in hot-spring systems," Journal of Volcanology and Geothermal Research, vol. 5, no. 1-2, pp. 116, 1979.

[16] C. Fouillac and G. Michard, "Sodium/lithium ratio in water applied to geothermometry of geothermal reservoirs," Geothermics, vol. 10, no. 1, pp. 55-70, 1981.

[17] S. Arnorsson, "Chemical equilibria in Icelandic geothermal systems-implications for chemical geothermometry investigations," Geothermics, vol. 12, no. 2-3, pp. 119-128, 1983.

[18] W. F. Giggenbach, "Geothermal solute equilibria. Derivation of Na-K-Mg-Ca geoindicators," Geochimica et Cosmochimica Acta, vol. 52, no. 12, pp. 2749-2765, 1988.
[19] W. F. Giggenbach and R. B. Glover, "Tectonic regime and major processes governing the chemistry of water and gas discharges from the Rotorua geothermal field, New Zealand," Geothermics, vol. 21, no. 1-2, pp. 121-140, 1992.

[20] S. P. Verma and E. Santoyo, "New improved equations for, and $\mathrm{SiO}_{2}$ geothermometers by outlier detection and rejection," Journal of Volcanology and Geothermal Research, vol. 79, no. 1-2, pp. 9-23, 1997.

[21] A. Ferhat Bayram, "Application of an artificial neural network model to a Na-K geothermometer," Journal of Volcanology and Geothermal Research, vol. 112, no. 1-4, pp. 75-81, 2001.

[22] I. Can, "A new improved $\mathrm{Na} / \mathrm{K}$ geothermometer by artificial neural networks," Geothermics, vol. 31, no. 6, pp. 751-760, 2002.

[23] Z. Xilai, H. Armannsson, L. Yongle, and Q. Hanxue, "Chemical equilibria of thermal waters for the application of geothermometers from the Guanzhong basin, China," Journal of Volcanology and Geothermal Research, vol. 113, no. 1-2, pp. 119-127, 2002.

[24] S. Kamel, "Application of selected geothermometers to Continental Intercalaire thermal water in southern Tunisia," Geothermics, vol. 41, pp. 63-73, 2012.

[25] F. Nitschke, S. Held, T. Neumann, and T. Kohl, “Geochemical characterization of the Villarrica geothermal system, Southern Chile, part II: site-specific re-evaluation of $\mathrm{SiO} 2$ and $\mathrm{Na}-\mathrm{K}$ solute geothermometers," Geothermics, vol. 74, pp. 217-225, 2018.

[26] M. Blasco, L. F. Auqué, M. J. Gimeno, P. Acero, and M. P. Asta, "Geochemistry, geothermometry and influence of the concentration of mobile elements in the chemical characteristics of carbonate-evaporitic thermal systems. The case of the Tiermas geothermal system (Spain)," Chemical Geology, vol. 466, pp. 696-709, 2017.

[27] J. C. Shen, X. G. Wang, L. F. Jia, and L. H. Gong, "The differences in the development of the geothermal reservoirs of the Guantao Group and conditions of well completion in the Jizhong and Huanghua depressions," Hydrogeology \& Engineering Geology, vol. 3, no. 8, pp. 40-43+54, 2004.

[28] X. Z. Zhao, F. M. Jin, Q. Wang, C. Y. Han, and X. Y. Dong, "Exploration and discovery of subtle deep buried hill and buried hill inner curtain hydrocarbon reservoir in Jizhong sag," China Petroleum Exploration, vol. 19, pp. 10-21, 2014.

[29] C. H. Gao, M. Zha, X. Z. Zhao, and P. Peng, "Migration systems and hydrocarbon accumulation models of buried hill reservoirs in Jizhong Depression," Lithologic Reservoirs, vol. 27, pp. 26-30+37, 2015.

[30] C. H. Gao, M. Zha, X. Z. Zhao, and F. M. Jin, "Hydrocarbon accumulation models and their main controlling factors in the deep buried hills of the Jizhong Depression, Bohai Bay Basin," Natural Gas Industry, vol. 37, pp. 52-59, 2017.

[31] Y. M. Zhang, J. Z. Tian, D. X. Yang et al., "Accumulation conditions and exploration direction of Cambrian Fujunshan Formation inside buried hills in Jizhong depression," China Petroleum Exploration, vol. 24, pp. 297-312, 2019.

[32] Y. Zhang, J. Y. Feng, Z. L. He, and P. W. Li, "Classification of geothermal systems and their formation key factors," Earth Science Frontiers, vol. 24, pp. 190-198, 2017.

[33] J. Chang, N. S. Qiu, X. Z. Zhao et al., "Present-day geothermal regime of the Jizhong depression in Bohai Bay Basin, East China," Chinese Journal of Geophysics, vol. 59, pp. 10021016, 2016. 
[34] Y. M. Zhang, J. Chang, N. Liu et al., "Present-day temperaturepressure field and its implications for the geothermal resources development in the Baxian area, Jizhong Depression of the Bohai Bay Basin," Natural Gas Industry B, vol. 5, no. 3, pp. 226-234, 2018.

[35] X. He and Y. Ma, "Hydrochemical features and formation mechanism of the Ordovician carbonate reservoir in North China Plate," Safety and Environmental Engineering, vol. 26, pp. 9-15, 2019.

[36] D. F. He, Y. Q. Cui, Y. Y. Zhang et al., "Structural genetic types of paleoburied hill in Jizhong depression, Bohai Bay Basin," Acta Petrologica Sinica, vol. 33, pp. 1338-1356, 2017.

[37] J. Li and Z. G. Zhang, "Characteristics of geothermal resources in Jizhong depression (Hebei region)," Journal of Hebei University of Technology, vol. 47, pp. 113-120, 2018.

[38] J. H. Du, H. W. Zou, B. S. Fei, H. Y. Lei, F. Z. Zhang, and Y. M. Zhang, Buried hill composite hydrocarbon accumulation zone of Jizhong depression, Science Press, 2002.

[39] B. J. Zhang, Y. L. Sun, X. L. Kang, L. Du, F. Xu, and Y. Y. Hu, "The study of formation conditions of karst geothermal water in Beijing and its peripheral areas based on hydrochemical analysis," Urban Geology, vol. 12, pp. 11-19, 2017.

[40] F. Li and J. H. Zeng, "Characterization of origin and evolution of formation water in buried hill of Jizhong depression, China, using multivariate statistical analysis of geochemical data," Geofluids, vol. 2017, Article ID 5290686, 15 pages, 2017.

[41] S. H. Wu, Q. Z. Cai, and S. M. Shi, Oilfield geology, Petroleum Industry Press, 2011.

[42] J. H. Zeng, Geofluids in sedimentary basins, China University of Petroleum Press, 2017.

[43] Y. Hou, Z. Shi, and W. Mu, "Fluid geochemistry of fault zone hydrothermal system in the Yidun-Litang area, eastern Tibetan Plateau geothermal belt," Geofluids, vol. 2018, Article ID 6872563, 13 pages, 2018.

[44] X. Wang, G. Wang, H. Gan, Z. Liu, and D. Nan, "Hydrochemical characteristics and evolution of geothermal fluids in the Chabu high-temperature geothermal system, Southern Tibet," Geofluids, vol. 2018, Article ID 8532840, 15 pages, 2018.

[45] X. Wang and X. Zhou, "Geothermometry and circulation behavior of the hot springs in Yunlong county of Yunnan in Southwest China," Geofluids, vol. 2019, Article ID 8432496, 16 pages, 2019. 